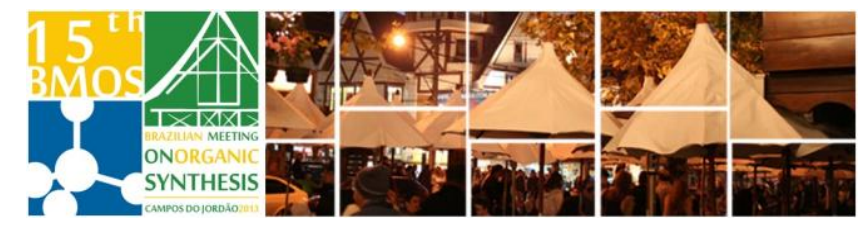

\title{
Studies aiming the synthesis of the indolizidine alkaloids $(+)$-Ipalbidine and (+)-Antofine
}

\author{
Ariane F. Bertonha ${ }^{1}$ (PG), Antonio C. B. Burtoloso ${ }^{1 \star}(P Q)$. \\ 1 - Laboratório de síntese orgânica Professor Warner Bruce Kover, Instituto de Química de São Carlos, Universidade de \\ São Paulo *antonio@iqsc.usp.br.
}

Keywords: (+)-Ipalbidine, (+)-Antofine and $\alpha$-chloroketone.

\section{INTRODUCTION}

The indolizidine skeleton is present in a large number of compounds with interesting biological profiles. The (+)-ipalbidine $\mathbf{1}$ and (+)-antofine $\mathbf{2}$ have, among others, analgesic and anticancer properties, respectively. However, there are few short, divergent and enantioselective syntheses for these compounds.
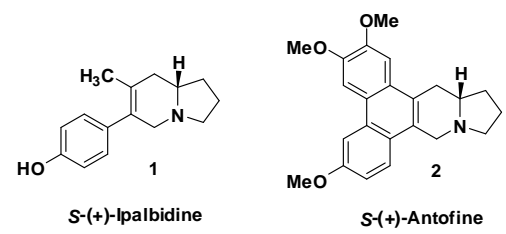

Figure 1. Structures of the target compounds.

This work presents a new route to obtain the indolizidine skeleton present in these alkaloids, employing a cyclization reaction from $\alpha$ chloroketones $\left(\mathrm{R}_{1}=\mathrm{CH}_{3}(+)\right.$-Ipalbidine, $\mathrm{R}_{2}=\mathrm{Ar}$, Phenanthroindolizidines), which can be easily prepared from (S)-prolinal (Scheme 1). The key steps of this strategy are: an olefination reaction (Wittig or Horner-Wadsworth-Emmons); the preparation of $\alpha$-chloroketones; and converting them into the indolizidine skeleton.

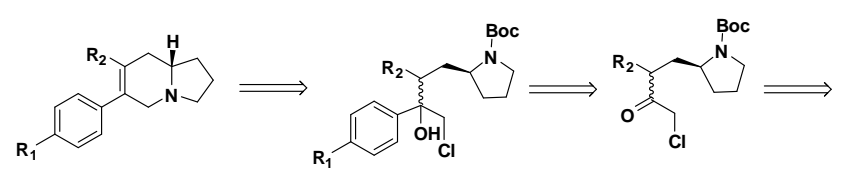

$$
\Longrightarrow \underbrace{\text { Boc }}_{\text {OEt }}
$$

Scheme 1. Retrosynthetic analysis strategy.

\section{RESULTS AND DISCUSSION}

Owing to its lower structural complexity, the studies were initiated by the synthesis of $(+)$-ipalbidine ${ }^{1}$. The a-chloroketone 8 was prepared from (S)-prolinal in 3 steps and with a $79 \%$ overall yield (scheme 2 ).

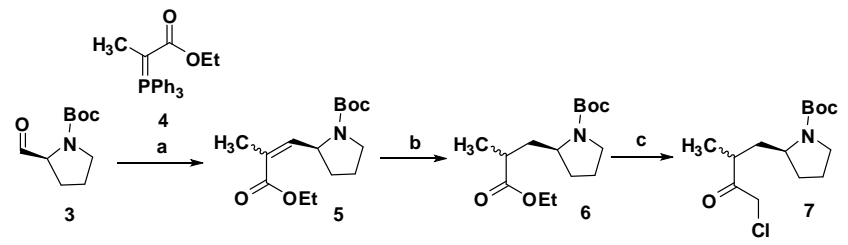

Scheme 2. a) DCM, r.t., $8 \mathrm{~h}(95 \%)$; b) $\mathrm{Ni}_{2} \mathrm{~B}, \mathrm{THF} / \mathrm{MeOH}$, $0^{\circ} \mathrm{C} \rightarrow$ r.t., 12 h (96\%); c) LDA, $\mathrm{ClCH}_{2} \mathrm{l}$, THF, $-78^{\circ} \mathrm{C}, 2 \mathrm{~h}$

(90\%).

Initial studies aiming the cyclization reaction from a-chloroketones were fruitless. Considering that, we next evaluated the cyclization from $\alpha$-chloroalcohols (installation of the aromatic ring prior to cyclization). In this study, phenyl magnesium Grignard was used as a model. After succeed in preparing $\alpha-$ chloroalcohol $\mathbf{8}$, we then studied the cyclization reaction (scheme 3 ). The best results were achieved when we employed phenol and trimethylsilyl chloride, followed by purification on Dowex 50. In possession of compound $\mathbf{9}$, it is now being converted into compound $\mathbf{1 0}$ by an elimination reaction ${ }^{2}$.

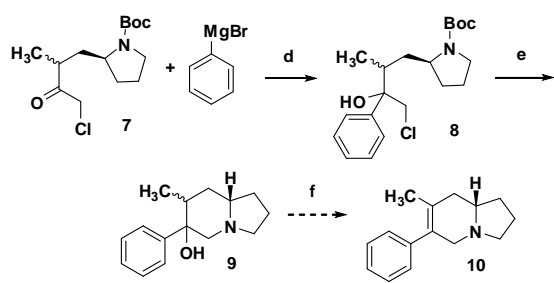

Scheme 3. d) $\mathrm{PhMgBr}, \mathrm{Et}_{2} \mathrm{O},-78^{\circ} \mathrm{C} \rightarrow$ r.t., $10 \mathrm{~h}(60 \%)$; e) $\mathrm{PhOH}, \mathrm{TMSCl}, \mathrm{DCM}$ (yield under assessment); f) 25\% $\mathrm{H}_{2} \mathrm{SO}_{4}$ reflux.

\section{CONCLUSION}

The strategy using a-chloroketones for the synthesis of indolizidine constitutes a new approach with reduced number of steps. This approach can be applied to obtain the (+)-ipalbidine, the $(+)$-antofine and other indolizidine alkaloids.

\section{ACKNOWLEDGEMENTS}

FAPESP, CNPq, IQSC-USP and DQ-UFSCar.

\section{REFERENCES}

Prado, V. S. Estudos visando a síntese do alcaloide indolizidínico (+)ipalbidina. Thesis (Master) - Universidade de São Paulo, Instituto de Química de São Carlos, São Carlos, 2012.

${ }^{2}$ Bøgesesø, K. P.; Arnt, J.; Lundmark, M. e Sundell, S. J. Med. Chem. 1987, 30, 142-150.

$15^{\text {th }}$ Brazilian Meeting on Organic Synthesis - $15^{\text {th }}$ BMOS - November 10-13, 2013 - Campos do Jordão, Brazil 